\title{
DIVERSIFIKASI NAFKAH DI PEDESAAN DALAM KONTEKS RELASI DESA-KOTA
}

\author{
Anik Susanti ${ }^{1}$, Nyimas Nadya Izana ${ }^{2}$ \\ Jurusan Sosiologi, FISIP, Universitas Brawijaya, Malang, Indonesia \\ e-mail: aniksusanti@ub.ac.id
}

\begin{tabular}{l}
\hline \multicolumn{1}{c}{ Article Info } \\
\hline Keyword: \\
Livelihood portfolio \\
Diversification of \\
livelihoods \\
Rural dweller
\end{tabular}

\section{Abstract}

This study aims to describe the diversification of livelihoods as a strategy achieved by the rural dweller to maintain and improve their standard of living. This issue is important to be studied in order to explore various alternative ways of the fundamental problem that is passed by them. There are four problems related to socio-economic life in rural areas, namely low labor productivity, land ownership that is getting narrower along with the large number of small farmers, relatively low household income and lower wages for agricultural laborers than construction and industrial workers. As a consequence, subsistence farming has weak prospects and cannot be relied on as the only source of livelihood for the rural population. Even though agricultural sector is no longer being promoted as a source of income, some rural residents continue to pursue farming while carrying out various supporting activities to fullfill their needs. In fact, there is a tendency for them to take advantage of the opportunities that exist in order to improve their standard of living. The rural population actually has various levels in maintaining the existence of life and increasing the standard of living of their household in accordance with the unique social, economic, ecological and cultural arrangements in an area. One of them is the focus of this research, namely the diversification of household livelihoods in rural areas in the context of rural-urban relations. We hope to find a formula that can support the capability of rural residents to diversify their livelihoods in response to urban development. To realize this goal, the research team has conducted investigations on: a portfolio of livelihood activities of rural small people in the context of the struggle for survival and improvement of their standard of living and (b) diversification of livelihoods carried out by small people in the context of rural-urban relations.

\section{Article Info}

Kata Kunci:

Portofolio mata pencarian

Diversifikasi mata

pencarian

Penduduk pedesaan

\section{Abstrak}

Penelitian ini bertujuan untuk mendeskripsikan diversifikasi mata pencarian sebagai strategi yang dilakukan oleh penduduk pedesaan untuk mempertahankan dan meningkatkan taraf hidupnya. Isu ini penting untuk dikaji guna menggali berbagai alternatif cara dari permasalahan mendasar yang dilalui mereka. Ada empat masalah yang berkaitan dengan kehidupan sosial ekonomi di pedesaan, yaitu produktivitas tenaga kerja yang rendah, kepemilikan lahan yang semakin sempit seiring dengan banyaknya petani kecil, pendapatan rumah tangga yang relatif rendah dan upah buruh tani yang lebih rendah dibandingkan buruh bangunan dan industri. Akibatnya, pertanian subsisten memiliki prospek yang lemah dan tidak dapat diandalkan sebagai satu-satunya sumber mata pencarian penduduk pedesaan. Meskipun sektor pertanian tidak lagi digalakkan sebagai 
sumber pendapatan, sebagian penduduk pedesaan tetap bertani sambil melakukan berbagai kegiatan penunjang untuk memenuhi kebutuhan hidupnya. Bahkan, ada kecenderungan mereka memanfaatkan peluang yang ada untuk meningkatkan taraf hidupnya. Penduduk pedesaan sebenarnya memiliki berbagai tingkatan dalam mempertahankan eksistensi kehidupan dan meningkatkan taraf hidup rumah tangganya sesuai dengan keunikan tatanan sosial, ekonomi, ekologi dan budaya di suatu wilayah. Salah satunya yang menjadi fokus penelitian ini, yaitu diversifikasi mata pencarian rumah tangga di pedesaan dalam konteks hubungan desa-kota. Kami berharap dapat menemukan formula yang dapat mendukung kemampuan penduduk pedesaan untuk mendiversifikasi mata pencarian mereka dalam menanggapi pembangunan perkotaan. Untuk mewujudkan tujuan tersebut, tim peneliti telah melakukan investigasi terhadap: (a) portofolio kegiatan mata pencarian masyarakat kecil pedesaan dalam rangka perjuangan untuk bertahan hidup dan peningkatan taraf hidup mereka dan (b) diversifikasi mata pencarian yang dilakukan oleh masyarakat kecil di konteks hubungan desa-kota.

\section{Pendahuluan}

Penelitian ini memiliki tujuan untuk mendeskripsikan diversifikasi nafkah sebagai strategi untuk mempertahankan dan meningkatkan standar hidup rakyat miskin di pedesaan. Isu ini penting dikaji untuk mengeksplorasi beragam jalan alternatif atas permasalahan mendasar yang dihadapi kaum lemah. Ada empat permasalahan terkait dengan kehidupan sosial ekonomi di pedesaan antara lain produktivitas tenaga kerja yang rendah, luas penguasaan lahan yang semakin sempit seiring dengan meningkatnya jumlah petani gurem, pendapatan rumah tangga relatif rendah serta upah buruh tani yang lebih rendah dari pada upah buruh bangunan dan industri (Suhariyanto, 2007). Konsekuensinya, usaha pertanian subsisten dianggap memiliki prospek yang suram dan tidak dapat diandalkan sebagai sumber penghidupan satu-satunya bagi penghidupan penduduk pedesaan.

Dalam rangka membantu mengatasi masalah penghidupan penduduk pedesaan, pemerintah telah menerapkan berbagai program seperti Program Keluarga Harapan (PKH), Jaminan Kesehatan Masyarakat (Jamkesmas), Beras untuk Keluarga Mikin (Raskin), Bantuan Siswa Miskin (BSM), Program Nasional Pemberdayaan Masyarakat (PNPM) Mandiri Perdesaan dan Kredit Usaha Rakyat (KUR). Program yang bersifat top down tersebut menempatkan pemerintah sebagai agen utama dalam implementasinya. Kurangnya pelibatan inisiatif masyarakat lokal dalam pemajuan penghidupan di pedesaan membuat keberhasilan program-program tersebut kurang optimal sehingga hasil akhirnya tidak menjadikan masyarakat menjadi lebih berdaya malah mengalami ketergantungan kepada negara.

Meskipun usaha pertanian tidak lagi menjanjikan sebagai tumpuan nafkah, sebagian penduduk pedesaan tetap menekuni usaha tani sembari melakukan ragam aktivitas penunjang demi mencukupi kebutuhan hidupnya. Malahan ada kecenderungan dari mereka untuk memanfaatkan peluang yang ada demi meningkatkan taraf hidup. Penduduk pedesaan sebenarnya memiliki berbagai mekanisme dalam mempertahankan eksistensi kehidupan dan meningkatkan standar hidup rumah tangganya sesuai dengan setting sosial, ekonomi, ekologi dan budaya khas di suatu kawasan. Penduduk pedesaan sebenarnya memiliki berbagai mekanisme dalam mempertahankan eksistensi kehidupan dan meningkatkan standar hidup rumah tangganya sesuai dengan setting sosial, ekonomi, ekologi dan budaya khas di suatu kawasan. Salah satunya adalah yang menjadi fokus penelitian ini yaitu diversifikasi nafkah rumah tangga di pedesaan dalam konteks relasi desa-kota.

Penulis tertarik mengangkat topik tentang diversifikasi nafkah rumah tangga di pedesaan dalam konteks relasi desa-kota karena beberapa alasan berikut: (a) pertarungan antara sektor kekotaan dan sektor perdesaan pada akhirnya akan memarjinalkan sektor pedesaan yang secara lebih spesifik 
adalah petani. Uniknya, di Desa Baturetno ditemukan petani yang konsisten pada usaha on farm dan off farm meskipun pertanian subsisten tidak lagi menarik generasi muda. (b) fenomena alih fungsi lahan untuk pembangunan fasilitas umum memang memaksa petani melepaskan lahan dan pekerjaannya, tetapi petani merupakan aktor yang rasional. Mereka mampu membuat pilihan yang paling menguntungkan sesuai dengan sumber daya, kepentingan, dan kontek sosialnya.

Di Baturetno dengan adanya pembangunan jalan tol sebagian masyarakat meresponnya sebagai peluang usaha seperti penyewaan kamar atau rumah, pembukaan warung makan dan warung kelontong. (c) Desa Baturetno yang jaraknya sekitar $14 \mathrm{~km}$ dari Kota Malang memudahkan relasi desa-kota sehingga pengaruh kehidupan urban turut mewarnai desa ini dalam aspek fisik, ekonomi, dan sosial. Pengaruh relasi desa-kota tidak melulu berdampak negatif karena sebagian kaum lemah memanfaatkan relasi ini untuk mencari nafkah dan meningkatkan taraf hidupnya. Di Desa Baturetno sebagian penduduknya melakukan komuter ke daerah sekitarnya yang bercorak periurban hingga masuk ke Kota Malang untuk bekerja.

Diversifikasi nafkah merupakan proses yang merujuk pada fenomena rumah tangga di pedesaan membangun ragam portofolio kegiatan dan kecakapan menggalang dukungan sosial dalam rangka perjuangan bertahan hidup dan meningkatkan standar kehidupannya (Ellis, 1998). Di Indonesia, bahasan tentang diversifikasi nafkah telah dirintis oleh Mazhab Bogor sebagai turunan dari kajian tentang sosiologi nafkah. Aliran pemikiran yang dimotori oleh Sayogjo ini berupaya untuk mengungkap akar persoalan dan kerentanan yang menyertai sistem penghidupan penduduk di pedesaan khususnya dari kalangan kaum marjinal. Ketidakpastian nafkah dan kelangkaan lapangan usaha yang membelenggu penduduk pedesaan bukannya bersumber dari sikap fatalistik ataupun ketidakcakapan dalam mengakses sumber daya yang tertanam dalam struktur sosial melainkan terdapat rintangan struktural dan institusional (Dharmawan, 2007). Dengan demikian, bentuk-bentuk strategi nafkah yang ditempuh setiap rumah tangga akan berbeda satu sama lain sesuai dengan struktur sosial di pedesaan.

Mazhab Bogor begitu memiliki perhatian pada upaya rakyat kecil pedesaan untuk bertahan ditengah belenggu struktural namun kurang memberikan perhatian pada upaya kreatif rakyat di pedesaan memobilisasi diversifikasi nafkah sebagai jalan ekspansif untuk meningkatkan taraf kehidupannya. Dengan menyandarkan diri pada Mazhab Bogor, peneliti bermaksud memberikan kontribusi temuan bahwa diversifikasi tidak sekadar masalah bertahan hidup dari belenggu struktural tetapi juga menyangkut persoalan menentukan pilihan dan memperluas kesempatan. Untuk mewujudkan maksud tersebut, peneliti akan melakukan studi kasus pada komunitas petani dan buruh di Desa Baturetno Kecamatan Singosari Kabupaten Malang.

Jarak Desa Baturetno dengan Kota Malang adalah sekitar $14 \mathrm{~km}$. Karena letaknya yang relatif dekat dengan pusat kota, maka penampakan fisik desa ini menunjukkan tanda-tanda wilayah periurban (WPU). WPU memiliki sejumlah karakteristik seperti penduduknya masih menggantungkan penghidupannya pada sektor pertanian walaupun sudah diketahui bahwa WPU menjadi sasaran perkembangan fisikal baru dari kota. Konsekuensinya adalah mulai beralihfungsinya lahan pertanian menjadi kawasan indutri maupun hunian. Tidak jarang, muncul konflik kepentingan antara mempertahankan lahan pertanian bagi sektor kedesaan dan di sisi lain melepaskan lahan pertanian untuk perkembangan fisik baru sektor kekotaan.

Tidak berlebihan kiranya bahwa WPU seolah-olah merupakan ajang pertempuran antara sektor kedesaan dan sektor kekotaan, di mana tidak pernah ada kenyataan empiris yang mengemukakan bahwa sektor kedesaan memenangkan peperangan ini (Yunus, 2008). Hilangnya lahan pertanian, menurunnya produktivitas pertanian, menurunnya komitmen petani terhadap lahan maupun kegiatan pertaniannya, hilangnya bidang pekerjaan pertanian, ketidaksiapan petani masuk ke sektor nonpertanian, dan hilangnya atmosfer kedesaan merupakan beberapa contoh dampak negatif dari aglomerasi Kota Malang yang bisa ditemukan di Desa Baturetno. Karenanya, rakyat kecil utamanya petani, buruh tani, dan pekerja serabutan merupakan pihak yang paling menderita kekalahan sehingga 
sangat menarik jika menggambarkan secara lebih detail tindakan survival dan ekpansif dalam konteks relasi desa dengan kota.

\section{Metode Penelitian}

Peneliti memilih metode kualitatif didasari beberapa alasan. Pertama, penelitian kualitatif dilakukan pada kondisi alamiah yang artinya peneliti membiarkan obyek penelitian berkembang apa adanya, tidak memanipulasi maupun memengaruhinya. Kedua, penelitian kualitatif memandang realitas sosial sebagai sesuatu yang holistik, kompleks, dinamis, penuh makna dan hubungan antar gejala bersifat interaktif (Moleong, 2007). Berdasarkan tujuan penelitian, metode kualitatif cocok terapkan karena peneliti melihat rakyat kecil di pedesaan melakukan diversifikasi nafkah.

Peneliti sengaja memilih lokasi penelitian di wilayah periurban di Kabupaten Malang. Desa Baturetno ditentukan sebagai lokasi penelitian karena: (1) sedang mengalami transisi dari kawasan yang berciri kedesaan menuju kawasan yang berciri kekotaan; (2) di desa ini sedang terjadi konversi lahan yang berpotensi memarjinalkan maupun memberikan peluang bagi kaum tani dan buruh.

Dalam penelitian kualitatif, penentuan subjek penelitian dilakukan dengan dua teknik yaitu snowball sampling dan purposive sampling. Namun, dalam penelitian ini digunakan snowball sampling karena peneliti belum mendapatkan keterangan yang memadai tentang calon informan yang dapat memberikan informasi terkait dengan masalah penelitian. Terkait dengan hal tersebut, peneliti membutuhkan informan kunci yang memahami situasi sosial di Desa Baturetno. Adapun informan kunci yang dimaksud adalah Kepala Desa Baturetno. Keterangan dari informan kunci tersebut akan peneliti gunakan untuk menentukan informan utama yang terkait dengan masalah penelitian. Apabila data yang disampaikan oleh seorang informan belum mencukupi, peneliti akan meminta sarannya untuk menentukan informan selanjutnya yang dirasakan dapat menjawab pertanyaan peneliti. Cara ini akan digunakan seterusnya hingga data yang diperoleh peneliti menjadi jenuh dan berhenti ketika data yang disampaikan tidak ada yang baru. Adapun kriteria informan utama yang penulis perlukan antara lain berasal dari kalangan petani, petani penggarap, maupun buruh serabutan yang melakukan diversifikasi nafkah. Mereka inilah yang paling rentan mengalami peminggiran dalam kontestasi antara kehidupan kekotaan yang merembes hingga ke perdesaan.

Data kualitatif dalam penelitian ini berupa narasi dan deskripsi yang diperoleh dari tiga sumber baik primer maupun sekunder, yaitu (1) kata-kata informan terpilih yang dicatat dalam catatan lapangan maupun yang direkam dengan menggunakan handphone; (2) aktivitas petani yang dicatat maupun difoto, dan (3) dokumen tertulis. Karenanya, data kualitatif dikumpulkan dengan menggunakan wawancara mendalam, pengamatan serta dokumentasi.

Wawancara mendalam dilakukan dalam suasana yang biasa dan wajar seperti dalam kehidupan sehari-hari. Selain itu, pelaksanaan wawancara perlu mempertimbangkan waktu dan suasana yang tepat. Jika wawancara dilakukan di rumah petani, waktu yang tepat pada petang hari selepas magrib ketika keluarga mereka sedang santai. Jika dilakukan di tegalan, waktu yang tepat ketika istirahat siang hari sekitar pukul 12.00 WIB. Wawancara dapat juga dilakukan pada situasi dan tempat yang lain asalkan petani tidak merasa terganggu. Pedoman wawancara yang digunakan hanya berupa garisgaris besar permasalahan yang akan ditanyakan. Supaya hasil wawancara dapat terekam dengan baik, peneliti menggunakan alat perekam suara dan kamera untuk menjamin keabsahan penelitian. Data yang tidak terungkapkan oleh informan dalam wawancara akan dicari melalui observasi pada aktivitas petani di sekitar aktivitas usaha taninya. Supaya hasil wawancara dan observasi lebih kredibel, peneliti melengkapinya dengan foto-foto yang diambil dari situasi kehidupan di Desa Baturetno.

Pelaksanaan pengumpulan data bersifat perspektif emik yaitu berdasarkan pada apa yang diucapkan, dirasakan, dan dilakukan oleh petani. Oleh sebab itu, pengumpulan data dari seorang petani dilakukan dengan menggunakan satu atau lebih teknik pengumpulan data. Adapun teknik pengumpulan data dalam penelitian ini yaitu wawancara mendalam, observasi berperan serta, dan dokumentasi. 
Analisis data adalah proses menyusun secara sistematis data yang berupa pernyataan dari para informan, data hasil pengamatan pada aktivitas rumah tangga petani di suatu lokasi, data kepemilikan, dan penguasaan lahan pertanian serta data hasil telaah dokumen. Sesuai dengan jenis data yang didapatkan, teknik analisa data menggunakan analisa deskriptif kualitatif. Analisa data kualitatif dilakukan dengan cara mengorganisasikan data ke dalam kategori, menjabarkan ke dalam unit-unit, melakukan sintesa, menyusun ke dalam pola, memilih hal yang penting, serta membuat kesimpulan sehingga mudah dipahami oleh diri sendiri dan orang lain.

Analisis data dalam penelitian ini menggunakan teknik deskriptif kualitatif dengan model Miles dan Huberman yang dilakukan pada saat pengumpulan data berlangsung dan setelah selesai pengumpulan data dalam periode tertentu (Sugiyono, 2007). Pada saat wawancara, peneliti sudah melakukan analisis terhadap jawaban petani. Jika jawaban petani terasa belum memuaskan, peneliti akan melanjutkan pertanyaan lagi sampai diperoleh data yang kredibel. Aktivitas analisis data meliputi reduksi data, penyajian data dan penarikan kesimpulan yang akan dijabarkan dalam langkahlangkah berikut.

1. Data yang terkumpul dari suatu situasi kehidupan petani dan buruh tani di Desa Baturetno (hasil wawancara, hasil observasi dan telaah dokumen pada satu periode pengumpulan data) dihimpun dalam catatan lapang secara rinci dan teliti.

2. Data dalam catatan lapang kemudian difokuskan pada petani (simbol I), buruh tani (simbol II) dan serabutan (simbol III) di Desa Baturetno. Data yang tidak penting dibuang.

3. Data yang terpilih dikategorikan berdasarkan pada portofolio aktivitas dan diversifikasi nafkah.

4. Hasil dari kategorisasi data tersebut disusun dalam pola hubungan agar mudah dipahami dan disajikan dengan teks yang bersifat naratif.

5. Kesimpulan sementara yang dibuat perlu didukung oleh bukti-bukti yang kuat pada tahap pengumpulan data, dan selanjutnya disusun agar menjadi kesimpulan yang kredibel. Dengan demikian, kesimpulan dapat digunakan untuk menjawab rumusan masalah.

Untuk menguji kredibilitas data dalam penelitian ini, peneliti menggunakan beberapa teknik, yaitu sebagai berikut.

1. Perpanjangan pengamatan yaitu kembali lagi ke lapang untuk melakukan pengamatan dan wawancara lagi dengan nara sumber yang pernah ditemui maupun yang baru. Bila setelah dicek kembali ke lapangan data sudah benar berarti data tersebut kredibel.

2. Triangulasi yang meliputi triangulasi sumber, triangulasi teknik dan triangulasi waktu. Triangulasi menggunakan sumber dilakukan dengan jalan (a) membandingkan datahasil wawancara (kata-kata) dengan data hasil observasi (tindakan yang tampak); (b) membandingkan data primer (hasil wawancara dan hasil observasi) dengan dokumen yang ada kaitannya dengan masalah penelitian. Triangulasi teknik dilakukan untuk mengecek data kepada sumber yang sama dengan teknik yang berbeda.

\section{Pembahasan}

Pedesaan kini tidak lagi memadai jika diidentifikasi melalui aktivitas pertanian. Meskipun sebagian besar penduduk pedesaan mengaku sebagai petani, nyatanya pemenuhan penghidupannya diperoleh dari berbagai sumber, aset dan aktivitas. Pernyataan penulis ini dapat dibuktikan melalui hasil studi lapang pada salah satu rumah tangga di Dusun Pakel, Desa Baturetno yang dikepalai oleh Pak Rosyidi (51 tahun). Pak Rosyidi memiliki seorang istri dan tiga orang anak laki-laki yang masingmasing anaknya berusia 19 tahun, 16 tahun dan 4 tahun. Menurut penuturan istrinya, Bu Iin, Pak Rosyidi bekerja sebagai petani yang merangkap menjadi buruh harian dan pencari rumput bagi ternak yang dirawatnya. 
Pekerjaan memburuh ini tidak terikat pada satu pemilik lahan saja karena pemilik lahan lainpun kalau memerlukan tenaga Pak Rosyidi juga akan dipenuhi. Pada sistem upah harian di tegalan, durasi bekerja antara pukul 05.30 sampai siang hari bagi buruh perempuan dan sampai sore hari bagi buruh laki-laki. Besarnya upah untuk pekerjaan mencangkul dan menggemburkan tanah, yaitu Rp35.000 per harinya. Sebuah keberuntungan bagi Pak Rosyidi bekerja pada pemilik lahan yang dianggap murah hati karena ia juga mendapatkan bonus berupa makanan dan rokok.

Terkadang bersama dengan empat sampai lima orang buruh tani lainnya, Pak Rosyidi menerima pekerjaan mencangkul dengan sistem borongan pada sebidang lahan milik juragan tani. Besarnya upah setiap buruh yang terlibat dalam sistem borongan ditentukan secara sama rata di antara mereka. Sementara itu, durasi bekerja bisa sampai malam hari saat panen tebu yang mencakup pekerjaan menebang batang tebu dan mengikat batang tebu yang sudah ditebang menjadi satu supaya mudah diangkut ke dalam truk. Untuk pekerjaan ini, Pak Rosyidi mendapatkan upah dengan sistem borongan.

Peluang kerja menjadi buruh tani tidak tersedia setiap hari karena bergantung pada musim panen tebu dan sistem pertanian lahan kering sehingga pada saat kemarau, para buruh tani banyak yang menganggur. Meskipun peluang kerja di tegalan sedang kosong, Pak Rosyidi tetap menyibukkan diri dengan merawat ternak berupa tiga ekor sapi milik sendiri dan lima ekor kambing milik orang lain dengan sistem bagi hasil. Penduduk Dusun Pakel menyebut sistem bagi hasil merawat ternak dengan istilah paro bathi. Pada sistem paro bathi ternak kambing, pemilik modal menyerahkan kambing kepada perawat kambing untuk dijaga kesehatannya dan dicarikan rumput. Kalau kambing sudah beranak pinak, jumlah anakan kambing yang akan dibagi dua antara pemilik dan perawatnya. Sementara itu pada paro bathi ternak sapi betina, anakan sapi yang lahir pertama akan menjadi milik perawat sedangkan anakan sapi yang terlahir berikutnya akan menjadi milik pemodal. Pada paro bathi sapi pejantan, bagi hasil berupa keuntungan penjualan ternak dibagi dua antara pemilik modal dan perawat ternak.

Keluarga Pak Rosyidi menganggap sapi sebagai investasi dan tabungan. Setelah menikah, Pak Rosyidi diberi hadiah oleh orang tuanya seekor anakan sapi betina. Setelah usia 2,5 tahun sapi bunting dan berhasil lahir seekor anakan sapi. Setelah tidak lagi menyusu kepada induknya anakan sapi dijual. Hasil penjualan sebagian dipergunakan untuk membeli keperluan hidup sehari-hari dan sebagian lainnya dipergunakan untuk merenovasi rumah secara bertahap yaitu dari rumah gedhek menjadi rumah gedong. Sepanjang memelihara ternak sapi, keluarga ini sudah sembilan kali menjual sapi baik berwujud anakan maupun sapi jantan dewasa. Keluarga ini biasanya melakukan transaksi penjualan sapi di pasar hewan desa setempat. Adapun tiga ekor sapi yang saat ini dipelihara akan dipersiapkan buat anak-anaknya kelak.

Peluang untuk memperoleh pendapatan dari memelihara ternak tidaklah rutin sehingga keluarga ini memperoleh dukungan finansial sehari-hari dari usaha jual es kelapa yang dilakukan oleh $\mathrm{Bu}$ Iin. Dengan memanfaatkan lahan milik orang tua Pak Rosyidi, setiap hari Bu Iin menjual dagangannya dari pukul 07.00 hingga pukul 16.00 WIB. Besarnya penghasilan dari menjual es kelapa tidaklah menentu dengan rentangan antara Rp50.000 sampai Rp200.000. Jika kondisi pembeli sedang ramai, Bu Iin bisa mendapatkan uang Rp200.000 dan jika kondisi pembeli sedang sepi, Bu Iin hanya mendapatkan uang Rp50.000. Meskipun demikian, Bu Iin selalu bersyukur sebab pekerjaan ini dilakukan sembari mengasuh anaknya yang bungsu.

Dukungan finansial sehari-hari secara tidak langsung juga berasal dari dua anak laki-laki Pak Rosyidi. Kakak beradik itu melakukan komuter ke Kota Malang dengan menggunakan sepeda motor untuk bekerja di tempat pembuatan mebel di daerah Blimbing dan Arjosari. Anak sulung Pak Rosyidi mendapatkan upah sebesar Rp300.000 dalam seminggu tetapi jika dihitung harian akan mendapatkan upah antara Rp50.000 sampai dengan Rp60.000. Sejak putus dari sekolah menengah, anak kedua Pak Rosyidi ikut kakaknya bekerja di tempat pembuatan mebel. Kedua anak ini ikut berkontribusi pada pemenuhan nafkah sehari-hari keluarga meskipun dari pihak orang tua tidak menuntut. 
Meskipun empat dari lima orang anggota keluarga ini bekerja, Bu Rosyidi mengaku pernah mengalami kesulitan finansial. Namun, ia mengaku tidak pernah meminjam kepada bank dan tetangga karena khawatir mengundang pergunjingan. Bu Rosyidi lebih baik bekerja binatu dan melakukan penghematan seperti memasak dengan menggunakan kayu bakar. Berdasarkan paparan yang diperoleh dari studi pada keluarga Pak Rosyidi, penulis mendapatkan beberapa temuan. Pertama, keluarga ini melakukan penganekaragaman jenis pekerjaan untuk memperbesar pendapatan keluarga demi tercukupinya kebutuhan subsisten. Kedua, keluarga ini memanfaatkan aset berupa sapi sebagai sarana untuk berinvestasi dan meningkatkan status sosialnya. Ketiga, keluarga ini memobilisasi anggota keluarganya untuk berkontribusi pada kelangsungan hidup keluarga.

Ketidakpastian tersedianya peluang kerja dan rendahnya upah memburuh tani mendorong sebagian penduduk di Desa Baturetno memilih menjadi buruh industri. Alih fungsi lahan dari pertanian ke nonpertanian membawa konsekuensi berupa munculnya pabrik-pabrik di Kecamatan Singosari. Keberadaan pabrik-pabrik tersebut memberikan harapan bagi penduduk setempat meskipun tidak memiliki kualifikasi pendidikan tinggi. Setidaknya, memburuh di pabrik lebih menunjang kebutuhan hidup layak ketimbang memburuh di sawah karena UMR buruh pabrik di Kabupaten Malang tahun 2018 sebesar Rp2.574.807.

Berikut ini contoh rumah tangga yang portofolio nafkahnya berasal dari memburuh di pabrik dan pekerjaan serabutan sebagaimana dituturkan oleh Ibu Saropah (41 tahun). Ibu Saropah memiliki suami yang berkerja sebagai buruh pada salah satu pabrik di Lawang. Pendapatan suami Ibu Saropah sebesar UMR Kabupaten Malang. Ibu Saropah sendiri memiliki pekerjaan sebagai pedagang pisang dan perkakas rumah tangga. Sementara itu, anak lelaki mereka bekerja sebagai buruh pada pabrik furniture di Desa Bedali sedangkan anak perempuannya bekerja sebagai karyawan pada toko mainan anak-anak.

Ibu Saropah setiap hari melakukan komuter dari Desa Baturetno ke Pasar Lawang dengan menumpang angkutan desa untuk menjual pisang. Ibu Saropah mendapatkan barang dagangan dari pengepul dan terkadang ia juga membelinya dari pasar jika kiriman pisang dari pengepul sedang kosong. Pada saat wawancara dilakukan, Ibu Saropah berhasil kulakan sepuluh tandan pisang dengan harga Rp225.000 yang pertandoannya berisi antara 5-6 sisir pisang. Jika direrata, pertandan pisang memiliki kisaran harga Rp22.500 dan setiap sisir pisang berharga Rp4.500. Apabila kualitas pisang lebih bagus lagi, harga kulakannyapun bisa lebih mahal. Bu Saropah menjual pisang persisirnya antara Rp12.000 sampai Rp15.000. Malahan kepada para pelanggan Bu Saropah sering memberikan harga yang relatif lebih murah dari pada harga umum.

Pada saat tidak ada kiriman pisang dari pengepul, Ibu Saropah beralih usaha menjadi penjual alas tidur, kompor, alat penanak nasi dan kain. Barang-barang keperluan rumah tangga tersebut dibelinya di Pasar Lawang untuk kemudian dijual kembali di Desa Baturetno secara kredit yang angsurannya ditentukan sebesar Rp50.000 per minggu. Sementara itu, dagangan kain Ibu Saropah dapatkan dari seorang kenalan yang kebetulan bekerja di pabrik yang mana pabrik tersebut sering memberikan bonus berupa kain batik. Karena kain batik jumlahnya berlebih untuk dipakai sendiri, ia meminta Ibu Saropah menjualkan dengan harga dasar Rp12.000. Ibu Saropah sendiri menjajakan kain batik seharga Rp15.000 dengan diantar suaminya selepas bekerja di pabrik. Untuk meminimalisir risiko dagangan tidak laku, Bu Saropah baru kulakan ketika ada pesanan dari pembeli.

Anak perempuan Ibu Saropah selepas lulus sekolah menengah atas melamar kerja di toko mainan karena orang tuanya tak mampu untuk membiayai ke perguruan tinggi. Dengan gaji sebesar Rp700.000 per bulan, ia bekerja dari Minggu sampai Sabtu sejak pukul 07.00 hingga pukul 14.00 WIB. Rincian pekerjaan yang dilakukan antara lain menjaga kebersihan mainan dan etalase, memberi kode batang (barcode) harga mainan, memeriksa stok mainan, menguasai keterampilan membungkus mainan sebagai kado, melayani pembeli dan melakukan tugas tambahan berupa piket harian. Keterampilan tersebut tidak memerlukan keahlian khusus sehingga pada awal masuk kerja ia dilatih majikannya membungkus boneka untuk hadiah. Ibu Saropah mengaku senang putrinya memiliki 
pendapatan sendiri dan bisa memenuhi sebagian kebutuhannya. Secara tidak langsung beban ekonomi yang menjadi tanggungan orang tua menjadi berkurang.

Sementara itu, anak laki-laki Ibu Saropah bekerja sebagai tukang mebel di Desa Bedali dengan upah harian sebesar Rp85.000 yang dilakukan sejak pukul 06.00-18.00 WIB. Ia menamatkan pendidikannya hingga sampai sekolah menengah pertama sehingga keterampilan pertukangan ia pelajari bukan dari pendidikan formal. Mula-mula ia bekerja sebagai kuli bangunan yang tugasnya membantu tukang bangunan. Tidak puas menjadi kuli bangunan yang berupah Rp60.000, sedikit demi sedikit ia memperlajari keterampilan tukang bangunan secara otodidak. Ia mengaku pendapatan menjadi tukang bangunan tidaklah pasti. Tetapi ketika ia mampu menunjukkan kinerja bagus dan membuat pengguna jasa menyukai hasil kerjanya, maka panggilan kerja menukang tidak pernah berhenti. Dari pekerjaan menukang, ia mampu membeli satu unit sepeda motor yang berguna untuk menunjang pekerjaannya.

Kondisi yang berbeda ditunjukkan oleh rumah tangga yang relatif banyak memiliki aset yang dianggap berharga oleh penduduk desa seperti tanah dan ternak. Portofolio nafkah rumah tangga tipe ini diarahkan untuk kegiatan yang sifatnya investasi dan akumulasi kekayaan sebab mereka menyimpan uang atau memelihara ternak tidak hanya sekadar mengantisipasi kondisi krisis yang tak terduga. Hasil dari keuntungan usahanya akan digunakan memperbesar skala usaha untuk mendapatkan keuntungan yang lebih besar pada masa mendatang. Berikut ini portofolio nafkah rumah tangga $\mathrm{Bu}$ Khoidah di Desa Baturetno yang memiliki tujuan akumulatif.

$\mathrm{Bu}$ Khoidah, pemilik toko kelontong, menceritakan riwayat usaha rumah tangganya dari awal menikah hingga saat penelitian ini dilakukan. Bu Khoidah dinikahi suaminya yang seorang pendatang pada usia 15 tahun. Menurut pandangan orang desa pada masa itu umur Bu Khoidah termasuk usia yang wajar untuk membina rumah tangga. Orang tua Bu Khoidah membekali rumah tangga putrinya dengan sebuah rumah tinggal dan sebidang lahan pertanian yang saat itu lumrah ditanami palawija. Orang tua Bu Khoidah tidak hanya memberikan rumah dan lahan pertanian kepadanya tetapi juga kepada saudara Bu Khoidah. Oleh karena itu, peneliti dapat memahami mengapa rumah Bu Khoidah dan saudara-saudaranya dibangun bersebelahan. Orang tua yang masih memegang tradisi Madura biasanya mewarisi kebiasaan untuk membangun rumah bagi anak-anaknya pada sebidang pekarangan yang sama atau paling tidak berdekatan. Tradisi ini memiliki tujuan untuk memelihara rasa solidaritas antar kelompok yang memiliki pertalian kekerabatan baik karena hubungan darah maupun hubungan perkawinan.

Sebelum bekerja sebagai tukang mebel, suami Bu Khoidah menjalankan usaha tani pada lahan warisan mertuanya sedangkan Ibu Khoidah mengurus rumah tangga. Hasil usaha tani berupa palawija sebagian dikonsumsi sendiri sedangkan sisanya dijual untuk mendapatkan uang tunai. Seiring berjalannya waktu muncul perusahaan mebel dan kebetulan suami Ibu Khoidah memiliki keterampilan pertukangan, maka ia beralih profesi sebagai tukang mebel. Konsekuensinya, rumah tangga ini bisa mendapatkan uang tunai secara rutin dan dapat menyisihkan sedikit demi sedikit untuk tabungan. Ketika anak pertama $\mathrm{Bu}$ Khoidah masuk sekolah dasar, pasangan suami istri ini mewujudkan ide membuka toko kelontong. Mulanya skala usaha toko kelontong masih kecil karena ragam barang yang dijual dan jumlah pelanggan masih sedikit. Keuletan Bu Khoidah membuat toko kelontongnya semakin berkembang dan laris sehingga setiap dua hari sekali $\mathrm{Bu}$ Khoidah harus kulakan.

Selama sepuluh tahun menjalankan usaha toko Bu Khoidah sudah memahami masa-masa laris dan sepi pembeli. Maka dari itu, Bu Khoidah selalu menyediakan barang-barang yang paling diminati pelanggannya seperti air minum dan rokok. Bu Khoidah tidak mematok harga yang terlalu tinggi demi menjaga kesetiaan pelanggannya sehingga ia pun tidak enggan kulakan di dua pasar yang berbeda asalkan mendapat harga barang yang lebih murah. Meskipun margin keuntungannya tidak terlalu banyak tetapi kesetiaan pelanggan inilah yang membuat tokonya terus bertahan ditengah persaingan dengan toko-toko kelontong di sekitarnya. Berikut penuturan Ibu Khoidah mengenai usaha toko kelontongnya: 
“...Biasanya belanja di Pasar Dengkol atau Pasar Singosari gitu, Mbak. Cuma kalau harga rokok itu kulaan lebih murah di Pasar Dengkol ya selisih 100 rupiah, ya kan lumayan. Ya, kalau sepi ya dibawah satu juta, tapi jarang. Biasanya kalau musim hujan saja sih sepi" (Wawancara 15 September 2018 di teras toko informan).

Sebagian keuntungan dari toko kelontong yang dipadukan dengan sebagian gaji suaminya, memberikan peluang kepada keluarga ini untuk terus menjalankan usaha tani dan ternak sapi pedaging melalui mekanisme bagi hasil. Penduduk desa melihat bagi hasil merupakan wujud gotong royong antara orang yang berkecukupan dengan orang yang kekurangan atau dalam istilah Clifford Geertz disebut sebagai shared poverty. Keluarga Bu Khoidah tidak lagi mengusahakan pertanian palawija yang bercorak subsisten seperti padi, jagung, dan kacang melainkan sudah mengusahakan tanaman tebu yang bersifat komersial. Usaha tani tebu ini dijalankan melalui tenaga buruh tani dengan upah harian atau upah borongan yang mana pemberi kerja tidak berkewajiban menyediakan makanan. Namun Bu Khoidah seringkali merasa kasihan kepada para buruhnya sehingga ia tetap memberikan makanan dan rokok.

Keluarga Bu Khoidah secara tersirat menempatkan usaha tani sebagai bentuk usaha sampingan. Kendatipun usaha tani tebu terancam gagal panen maupun terkena dampak fluktuasi harga gula tetapi risiko itu tidak akan mendatangkan dampak krisis subsistensi yang mendalam. Ragam usaha yang digeluti keluarga $\mathrm{Bu}$ Khoidah menjadi katup pengaman karena kerugian yang menimpa usaha tani akan tergantikan oleh keuntungan rutin dari usaha tokonya ataupun dari gaji bulanan suaminya.

Strategi nafkah yang agak berbeda ditempuh oleh rumah tangga yang memiliki portofolio nafkah dari usaha tani sebagai pendapatan utama sementara usaha peracangan sebagai sumber pendapatan penunjang sebagaimana yang dialami oleh Keluarga Bu Rodhiyah. Bu Rodhiyah setiap hari menyibukkan diri mengelola warung peracangan yang memudahkan para tetangganya mendapatkan barang yang paling sering digunakan dalam keseharian. Istilah warung peracangan mewakili unit dan aktivitas usaha skala gurem yang menjual aneka barang seperti beras, gula, kopi, mie instan, telur, sabun, kerupuk, makanan ringan, dan rokok. Bu Rodhiyah merintis usaha ini memerlukan modal awal sebesar kurang lebih Rp500.000 sehingga ragam barang yang dijual juga sedikit.

Sejalan dengan pernyataan $\mathrm{Bu}$ Khoidah pada penjelasan dimuka maka Bu Rodhiyah juga sepakat bahwa dagangan yang paling laris adalah rokok. Dalam satu hari Bu Rodhiyah mampu memperoleh pendapatan kotor sebesar Rp500.000 saat pembeli ramai sedangkan saat pembeli sepi ia hanya mendapatkan uang sebesar Rp300.000. Meskipun keuntungan yang diperoleh tidak besar tetapi warung peracangan ini merupakan penyokong utama saat usaha tani belum memberikan hasil. Besarnya penghasilan dari pertanian bergantung pada pola tanam, jenis tanaman, serta kemampuan petani dalam mengelola faktor-faktor produksi dan risiko usaha tani. Untuk mengoptimalkan pendapatan dari ladang, keluarga Bu Rodhiyah menerapkan sistem tanam tumpang sari.

Sistem tanam tumpang sari yang terdiri atas tebu sebagai tanaman komersial, tomat, dan cabai sebagai tanaman hortikultura serta singkong sebagai tanaman palawija mencerminkan bentuk tindakan rasional petani untuk memaksimalkan keuntungan dan meminimalisir keuntungan. Sedikit sekali petani yang mencatat secara detail input dan output usaha taninya tetapi bukan berarti mereka tidak memperhitungkan untung rugi. Jika dibandingkan dengan sistem monokultur, sistem tanam tumpang sari lebih memberikan rasa aman kepada petani karena kegagalan panen salah satu tanaman bisa ditutup dengan keuntungan dari panen tanaman yang lain. Bu Rodhiyah menceritakan pengalaman keluarganya dalam mengusahakan tanaman tebu.

"Tanam tebu itu susah. Waktunya setahun lebih. Kalau rendemen rendah untunge ya sedikit. Lahane Bapak ada tiga perempat hektar, hasile tebu taun kemarin ada 70 tonan. Biayane hampir 27 jutaan kadang lebih. Makane diisi tebu, singkong, tomat, cabe gitu Mbak kalau di sana." (Wawancara 09 September 2018). 
Berdasarkan petikan wawancara tersebut, peneliti membuat simulasi perhitungan kasar atas pendapatan rumah tangga petani dari hasil panen pertama pada sebidang lahan tebu seluas 0,75 hektar. Perhitungan ini berdasarkan sistem bagi hasil pengolahan gula antara petani dan pabrik gula dengan rasio sebesar 66:34. Adapun rendemen dalam simulasi ini ditentukan sebesar 7,5\% berdasarkan catatan Dinas Tanaman Pangan, Hortikultura, dan Perkebunan Kabupaten Malang (Radar Malang, 16 April 2018).

Tabel 1. Ilustrasi Penghitungan Pendapatan Petani Tebu Pada Tingkat Rendemen 7,5\%

\begin{tabular}{|c|l|c|}
\hline No & \multicolumn{1}{|c|}{ Rincian } & Satuan \\
\hline 1 & Biaya produksi & 27 juta \\
\hline 2 & Hasil panen & 70 ton \\
\hline 3 & Rendemen & $7,5 \%$ \\
\hline 4 & Produk gula dari 70 ton tebu dengan rendemen $6,5 \%$ & $7,5 \% \times 70$ ton $\rightarrow 5,25$ ton \\
\hline 5 & Proporsi bagi hasil petani dengan pabrik gula & $66: 34$ \\
\hline 6 & Gula yang diperoleh petani & $66: 100 \times 4,55$ ton $\rightarrow 3,465$ ton \\
\hline 7 & Harga pokok pembelian gula tahun 2018 & 9700 \\
\hline 8 & Pendapatan kotor petani & 33,6105 juta \\
\hline 9 & Pendapatan bersih petani & 6,6105 juta \\
\hline
\end{tabular}

Sumber: Dinas Tanaman Pangan, Hortikultura, dan Perkebunan Kabupaten Malang, 2018.

Jika pendapatan bersih tersebut direrata perbulan selama setahun, pendapatan bersih setiap bulannya sebesar Rp550.875. Pendapatan tersebut jelas tidak mencukupi untuk membiayai kebutuhan rumah tangga sehari-hari sehingga keluarga ini juga memelihara seekor sapi. Sebenarnya keluarga ini dapat menjual sapi seminggu menjelang Iduladha karena pada saat itulah harga sapi bisa mencapai Rp12.000.000. Sulitnya mendapatkan rerumputan hijau pada musim kemarau memaksa keluarga ini untuk menjual sapi pada akhir September 2018 sehingga sapi hanya laku seharga Rp8.000.000.

Untuk memaksimalkan keuntungan dari budi daya tebu, petani umumnya menggunakan metode keprasan. Metode ini sesuai dengan sifat tebu sebagai tanaman tahunan. Sekali tebu ditanam dan masuk siklus produksi membutuhkan waktu selama empat tahun lagi untuk membongkar ratoon dan menanaminya lagi. Oleh karena itu, pascapanen pertama, petani melakukan keprasan rata-rata tiga kali untuk menjaga kualitas rendemennya. Metode keprasan lebih menghemat biaya produksi dan hemat waktu. Petani menyadari bahwa keprasan yang melebihi dua kali menghasilkan produk tebu yang tidak bisa dipastikan kualitas rendemennya. Malahan jika terlalu banyak hujan seperti tahun 2017 juga berisiko mendapatkan rendemen rendah hingga 6\% (Kompas Edisi 15 Mei 2017).

Tingkat rendemen tebu secara nyata berpengaruh pada kesejahteraan keluarga petani. Ilustrasi serupa akan diterapkan pada Tabel 2. dengan tingkat rendemen 6\% akibat musim hujan.

Tabel 2.Ilustrasi Penghitungan Pendapatan Petani Tebu Pada Tingkat Rendemen 6\%

\begin{tabular}{|c|l|c|}
\hline No & \multicolumn{1}{|c|}{ Rincian } & Satuan \\
\hline 1 & Biaya produksi & 27 juta \\
\hline 2 & Hasil panen & 70 ton \\
\hline 3 & Rendemen & $6 \%$ \\
\hline 4 & Produk gula dari 70 ton tebu dengan rendemen $6,5 \%$ & $6 \% \times 70$ ton $\rightarrow 4,2$ ton \\
\hline 5 & Proporsi bagi hasil petani dengan pabrik gula & $66: 34$ \\
\hline 6 & Gula yang diperoleh petani & $66: 100 \times 4,2$ ton $\rightarrow 2,772$ ton \\
\hline 7 & Harga pokok pembelian gula tahun 2018 & 9700 \\
\hline 8 & Pendapatan kotor petani & 26,8884 juta \\
\hline 9 & Pendapatan bersih petani & 0,1116 juta \\
\hline
\end{tabular}


Tidak hanya perihal teknis perawatan tebu, tetapi juga infrastruktur pabrik gula turut memengaruhi tingkat rendemen. Demikian juga dengan kebijakan pergulaan nasional ternyata memberikan tekanan tersendiri bagi keluarga petani. Konsekuensinya, secara teknis petani menempuh strategi alih usaha tani dari tanaman tebu ke tanaman pangan atau ke tanaman sengon. Sementara itu, secara sosial pelestarian tradisi gotong royong merupakan salah satu katup pengaman saat menghadapi krisis.

Desa Baturetno merupakan desa yang memiliki karakter periurban karena jaraknya yang relatif dekat dengan pusat kota kecamatan dan akses yang mudah ke Kota Malang. Perluasan Kota Malang ke daerah pinggiran ternyata memberikan implikasi pada dinamika kehidupan penduduk desa. Ketidakseimbangan antara kebutuhan dengan ketersediaan lahan untuk nonpertanian membuat harga lahan menjadi sangat mahal. Kurang prospektifnya usaha tani ditambah dengan kebijakan pembebasan lahan untuk kepentingan umum maka petani terdorong untuk melepaskan lahannya. Konsekuensinya akan terjadi alih fungsi lahan dari pertanian ke pemukiman atau industri.

Fenomena ini ternyata mendapatkan sikap dan tindakan yang beragam dari petani. Di satu sisi, terdapat petani yang awalnya menekuni usaha pertanian sebagai sumber nafkah utama terpaksa menyesuaikan diri dengan merubah matapencariannya ke sektor informal yang lain seperti perdagangan skala kecil dan jasa. Di desa ini, pembebasan lahan menimbulkan dampak yang paling kentara yaitu munculnya jutawan dari kalangan petani. Ada petani yang memanfaatkan hasil penjualan tanah kepada pemerintah tersebut untuk membeli lahan pertanian yang baru, ada yang menggunakan untuk menunaikan ibadah keagamaan, dan menyediakan tabungan untuk masa depan anak-anaknya. Tentu saja, tidak semua petani yang terdampak pembebasan lahan akan menerima kebijakan tersebut karena terdapat petani yang keberatan terhadap harga beli yang ditetapkan pemerintah yang dianggap tidak memenuhi rasa keadilan masyarakat.

Di sisi lain, masih ada petani yang terus menekuni usaha tani sembari melakukan ragam aktivitas sebagai sumber nafkah penunjang seperti menjadi kuli bangunan, pedagang kecil, tukang ojek dan peternak. Semua aktivitas ini semata-mata merupakan wujud strategi nafkah yang meliputi pilihan atas beberapa sumber nafkah yang tersedia di dalam masyarakat. Adapun strategi nafkah rumah tangga di Desa Baturetno antara lain (a) memobilisasi anggota keluarga dalam beragam pekerjaan walaupun dengan upah yang rendah, (b) memelihara ikatan kekerabatan dan patronase untuk memberikan perlindungan saat terjadi krisis, (c) melakukan diversifikasi nafkah yang terdiri atas usaha on farm, off farm, dan nonfarm, dan (d) melakukan komuter ke kota jika sumber nafkah di desanya tidak lagi ada.

Beberapa komponen dari konsep portofolio nafkah di Desa Baturetno akan diuraikan sebagai berikut. Pertama, nafkah lebih dari sekadar pendapatan. Pendapatan mengacu pada pendapatan tunai yang diperoleh rumah tangga ditambah dengan pembayaran dalam bentuk natura yang memiliki nilai di pasar harga. Komponen dalam wujud pembayaran tunai dari pendapatan termasuk item seperti penjualan hasil panen dan ternak, gaji, sewa, dan sewa. Komponen dalam wujud natura mengacu pada konsumsi akan hasil panen yang ditanam sendiri, upah dalam bentuk makanan dan pertukaran barang konsumsi yang dilakukan diantara rumah tangga di komunitas pedesaan.

Nafkah tidak hanya sekadar pendapatan, baik yang berbentuk uang tunai maupun yang berbentuk natura, tetapi juga meliputi kelembagaan sosial seperti kekerabatan, keluarga, desa, relasi gender, dan hak milik yang diperlukan untuk mendukung dan memberlanjutkan standar kehidupan yang berlaku dalam suatu komunitas. Jaringan sosial dan kekerabatan sangat penting dalam memfasilitasi dan menjaga keberlanjutan ragam portofolio pendapatan. Kelembagaan sosial juga sangat urgen dalam memaknai hambatan dan opsi yang tersedia bagi individu maupun keluarga sesuai dengan perbedaan gender, pendapatan, kesejahteraan, akses, dan aset. Sebagai contoh, perbedaan hak dalam mengakses tanah seringkali merupakan determinan kunci dalam membedakan strategi nafkah antara rumah tangga miskin dengan rumah tangga yang berkecukupan. Selain itu, pengecualian sosial pada tindakan yang diperbolehkan bagi perempuan akan membuat perbedaan besar pada opsi nafkah yang tersedia bagi perempuan bila dibandingkan dengan laki-laki. 
Nafkah juga termasuk akses dan keuntungan yang didapat dari layanan publik yang disediakan oleh negara seperti pendidikan, layanan kesehatan, jalan, dan suplai air. Temuan penelitian tentang kemiskinan sering menyatakan adanya kecenderungan dari ketentuan layanan umum memiliki bias terhadap lokasi, komunitas, serta kelompok sosial yang lebih baik dan aksesibel sehingga mempertajam deprivasi material yang dialami oleh kaum miskin sebagai akibat dari ketidakcukupan level aset dan pendapatan.

Diversifikasi nafkah tidak bisa disamakan dengan diversifikasi pendapatan. Meskipun demikian, kajian ekonomi tentang diversifikasi memiliki fokus pada sumber pendapatan yang berbeda dan keterhubungannya dengan tingkat pendapatan, distribusi pendapatan, aset ,dan hasil panen. Istilah ragam pendapatan mengacu pada komposisi pendapatan rumah tangga pada saat tertentu sedangkan diversifikasi nafkah mengandung makna proses sosial aktif dimana rumah tangga nampak melibatkan diri dalam portofolio aktivitas yang semakin kompleks sepanjang waktu. Kajian ekonomi membedakan antara beberapa kategori dari sumber pendapatan ketika mengacu pada ragam portofolio pendapatan. Pembuatan kategori tidaklah dilakukan secara serampangan karena kategori itu mengacu pada pasar tenaga kerja yang berbeda dengan beragam fitur musiman, keberlanjutan, hambatan masuk, lokasi, dan potensi pertumbuhan pendapatan. Individu dan rumah tangga yang berbeda mungkin saja memiliki potensi akses yang beragam pada sumber pendapatan sehingga partisipasi pada sumber ini akan berdampak secara berbeda pada kemiskinan dan distribusi pendapatan.

Adapun kategori utama sumber pendapatan yaitu farm, off farm, dan nonfarm. Farm income termasuk peternakan, pendapatan panen, dan meliputi konsumsi dalam bentuk barang dari hasil panen diladang sendiri dan pendapatan tunai dari hasil penjualan panen. Off farm income secara khas mengacu pada upah atau pertukaran tenaga kerja pada usaha tani milik orang lain. Off farm juga termasuk pembayaran tenaga kerja dalam bentuk natura, seperti sistem bagi hasil dan kontrak kerja nonupah yang lain dibanyak bagian negara berkembang. Nonfarm income mengacu pada sumber pendapatan nonpertanian. Beberapa kategori kedua dari nonfarm income umumnya teridentifikasi sebagai berikut yaitu: (a) upah tenaga kerja nonfarm di pedesaan; (b) wirausaha bidang nonfarm di pedesaan; (c) pendapatan properti; (d) remitan dari kota dalam batasan negara.

\section{Simpulan}

Bahwa portofolio aktivitas penghidupan rakyat kecil pedesaan dalam rangka perjuangan bertahan hidup dan peningkatan standar kehidupannya tidak hanya bertahan dalam satu pekerjaan, ada beberapa perkerjaan yang mereka geluti. Selain itu anggota keluarganya juga ikut membantu di dalam meringankan beban orang tua dan berani mengambil risiko di dalam menjual barang dagangannya sampai melakukan komuter. Sedangkan, rakyat kecil di pedesaan melakukan diversifikasi nafkah dalam konteks relasi desa-kota di Desa Baturetno Kabupaten Malang dengan cara bekerja serabutan atau bisa dikatakan dari pertanian ke nonpertanian selama pekerjaan itu bisa mereka lakukan. Dengan ungkapan lain, sebagian besar penduduk pedesaan mengumpulkan pendapatan dari berbagai sumber serta memanfaatkan asetnya untuk menunjang berbagai aktivitas yang memperbesar nafkahnya. Diversifikasi nafkah yang dilakukan oleh penduduk pedesaan dilandasi oleh dua motif yaitu motif pendorong dan motif penarik. Adapun motif pendorong adalah untuk menganekaragamkan aset dan aktivitas sehingga dapat mengurangi risiko, memitigasi adanya krisis serta meminimalisir biaya transaksi. Sementara itu, motif yang menarik individu dan rumah tangga untuk melakukan diversifikasi adalah mengombinasikan keterampilan dan sumber daya yang dimiliki individu dan rumah tangga dengan tujuan meraih keuntungan. Contohnya, melengkapi usaha pertanian dengan usaha peternakan.

\section{Daftar Pustaka}

Dharmawan, A. H. (2007). Sistem Penghidupan dan Nafkah Pedesaan: Pandangan Sosiologi Nafkah (Livelihood Strategy) Mazhab Bogor. Jurnal Transdisiplin Sosiologi, Komunikasi, Dan 
$\begin{array}{lcc}\text { Ekologi } & \text { Manusia, } & 1(2), \\ \text { https://journal.ipb.ac.id/index.php/sodality/article/viewFile/5932/4609 }\end{array}$

$169-192$.

Ellis, F. (1998). Household strategies and rural livelihood diversification. Journal of Development Studies, 35(1), 1-38. https://doi.org/10.1080/00220389808422553

Yunus, Hadi Sabari. (2008). Dinamika Wilayah Peri Urban Determinan Masa Depan Kota. Pustaka Pelajar.

Moleong, L. J. (2007). No Title. PT. Remaja Rosdakarya.

Sugiyono. (2007). Metode Penelitian Kualitatif Kuantitatif dan R\&D. Alfabeta.

Suhariyanto, K. (2007). Kinerja dan perspektif kegiatan non-pertanian dalam ekonomi pedesaan. 2006, 1-11 